Filip Peovski ${ }^{1}$

Gjorgji Gockov²

\title{
ASSESSING THE EUROPEAN CENTRAL BANK'S UNCONVENTIONAL MEASURES - A RECURSIVE VAR APPROACH
}

\begin{abstract}
Unconventional monetary measures utilization has proven to be of great importance in maintaining monetary and economic stability after the Great Recession. However, we aim to test this conclusion through the impact of the quantitative easing implemented by the European Central Bank. Observed through generated shocks in the balance sheet of the Eurosystem as our main variable, we tested whether quantitative easing reestablished economic growth and rose price levels, mainly through lowering borrowing costs for banks, thus helping in the post-crisis recovery. To prove our hypotheses we construct a recursive VAR model estimated in levels using 2014M05$2018 M 12$ data. The model incorporates variables such as the industrial production and the HICP, as output and price level proxies, and financial components such as the EONIA-MRO spread and the CISS index. The results show that the expansion shocks of the consolidated balance sheet have a positive temporary influence on industrial production and the HICP, but the reaction of the former seems to be 2.24 times greater. On the other hand, we find out that quantitative easing has an expected negative impact in widening the EONIA-MRO spread. Furthermore, we could not confirm the theoretically expected accommodative impact on financial stress.
\end{abstract}

Keywords: Unconventional monetary measures, price stability, policy interest rates, recursive VAR model

JEL: C32, E43, E52, E58

1 Teaching and Research Assistant, Faculty of Economics - Skopje, "Ss. Cyril and Methodius" University, e-mail: peovski@eccf.ukim.edu.mk

2 Associate Professor, Faculty of Economics - Skopje, "Ss. Cyril and Methodius" University, e-mail: gockovg@eccf.ukim.edu.mk 


\section{INTRODUCTION}

After the highly distortive economic episodes of the Great Depression and World War II, developed economies never again experienced so potent recessions. The slow buildup of economic tensions mainly on the financial markets in the U.S. eventually produced one of the greatest economic slumps - the Great Recession. One of the financial system flaws was the inadequate prudent supervisory framework (particularly for the banking system) leading to undervalued portfolio risk and the poorly specified credit rating set by the credit rating agencies, as noted by Carlin and Soskice (2015). The emerging housing bubble in the U.S. and the rising popularity of the mortgage-backed securities implicitly held potentially disastrous consequences. Consequently, the financial crisis quickly leaked in the Euro Area progressing into economic and sovereign debt crisis afterward. However, dealing with such kinds of economic shocks can be a real problem regarding a monetary union. When a specific country becomes a monetary union member, such as the Eurozone, it abandons its autonomous monetary policy - a powerful tool in achieving macroeconomic stabilization (Baldwin and Wyplosz, 2009). Furthermore, this raises potential threats from over-extensive fiscal expansion, which correlates with increased government indebtedness. The crisis had its roots deeply into the financial system so the standard monetary channels utterly failed. Since the conventional approach didn't provide enough stimulus, some central banks ${ }^{3}$ turned to a new and seemingly unconventional approach.

This paper contains the following structure. In Section 2 we briefly focus on the literature review regarding the topic and the incorporated model. In sections 3 and 4 we explicate the methodology implemented for this research as well as the results and their discussion. In Section 5 we set a series of potential questions and concepts regarding the future usage of the UMP (unconventional monetary policy). In the last section, we conclude the research results as well as establish implicit questions that might inspire future research on the same topic.

\section{Literature review}

In this section we provide a brief review of the related literature of previous researches regarding the topic of unconventional monetary policy incorporating various VAR, regression, and event study approaches in estimating or studying the dynamics of the UMPs macroeconomic impact. Generally, empirical researches are supporting the thesis that unconventional policies generate positive macroeconomic effects.

3 Such as the Federal Reserve System, the Bank of England, the Swedish Riksbank, the Bank of Japan, and of course, the ECB. 
The efficiency of conventional interest rate policy has been analyzed by Peersman (2011), noting that unlike the UMP, its shock transmission spreads swiftly throughout the economy, reaching its peak around 12 months after the initiation. Also, he notes that the unconventional approach positively affects crediting.

Eser and Schwaab (2013) analyze the impact of the Securities Markets Programme (SMP) on the 5-year government bond yields and their volatility through a panel regression with dummy variables indicating the start of the two separate episodes of purchases by this program. The idea behind the SMP was to lower the highly divergent bond yields of those countries that faced sovereign debt crises. According to their results, the Greek bonds reacted with the greatest fall in yields ranging from -17 to -21 b.p. on a $€ 1$ billion purchase. Portuguese bonds faced -6 to -9 b.p. yield lowering, -4 to -6 b.p. for the Spanish, -3 b.p. for the Irish bonds, and ranging from -1 to -2 b.p. for the Italian bonds. They also denote that the start of the SMP generated a much greater impact on lowering yields, unlike the reaction when the program was restarted in 2011.

Boeckx, Dossche, and Peersman (2014) estimate the VAR model in levels with monthly data for the 2007M1-2014M12 period with 3 lags to grasp the overall monetary impact during the crisis and the post-crisis period before the quantitative easing begun. For example, the usage of the output and the price level as targeted variables leads to a conclusion that the former reacts significantly reaching its peak in roughly 6 months after the conventional interest rate policy shock. Moreover, the money market spread notably drops and credit expansion is stimulated through unconventional measures.

On the other note, Gambacorta, Hofmann, and Peersman (2014) conclude that the shocks to the central bank's balance sheet (which is the most common proxy for UMP) generate fairly weaker and less persistent, but significant, however, reaction of the inflation. Unlike the previous research, they focus only on the 2008M12011M6 period, using monthly data. Their panel VAR approach allows them to further analyze the cross-country economic relations and shock spill-over in 8 developed economies. They include the VIX indicator (implied stock market volatility index) of the respective stock market indices. On that note, the UMP impact on them is negative and lasts for almost a year, after which gradually loses power. Besides the focus on typical macro variables, the usage of components such as the VIX and CISS indicators for stock market volatility and market stress helps in determining their relationship with the UMPs. Sign restricted SVARs can be used to estimate the previously stated, concluding that a negative and significant relationship between these variables and the balance sheet expansion is present in the EA (see Gambacorta, Hofmann and Peersman, 2014; Boeckx, Dossche and Peersman, 2014). 
Hálová (2015) on the other hand, focuses on the impact of the UMPs in the EA on the national economies in Central and East European countries, using monthly data from the 2008-2014 period. In her panel VAR model, apart from the balance sheet as an indicator for UMP, she uses the shadow policy rate as an unconventional measure proxy incorporating the balance sheet expansion and the interest rate policy into one variable. We follow this same path, but for a different time frame and simply for robustness check. For the theoretical and practical approach of the shadow rate we kindly recommend the paper published by Wu and Xia (2014). The model indicates that shocks to this variable generate substantial output reaction while the inflation reacts less significantly.

Hafemann and Tillmann (2017) study the effects of monetary policy shocks at the euro level, specifically for the 2002M01-2016M10 timeline. Their estimated SVAR model with sign restrictions consists of four baseline variables such as the log of industrial production, the log of the harmonized index of consumer prices, the corporate bond spread, and the shadow rate. To study shock transmission, they add different fifth variables spanning from the unemployment rate to government bond yields. Their main results suggest a minor, but significant, effect on output and inflation. However, their country-specific models indicate heterogeneous reactions of the targeted variables. The largest reactions of the industrial production are experienced in the large euro members, while the inflation gradually degrades in its shock reaction, which is far different from the previously stated researches.

A similar path is followed by Zabala and Prats (2020) in their four-variable SVAR model. As in a vast number of researches regarding unconventional policy, they focus on the reactions of real GDP and HICP on generated shocks by the ECB's total asset size. The EONIA rate is used as a monetary stance proxy. A larger time interval spanning from 2007-2018 is of interest, but, using quarterly data. As impulse response analysis is the focal point of VAR studies, they find out that the UMPs im-

plemented by the ECB have a positive and significant impact on real GDP reaching its peak in the second quarter. The response of prices to balance sheet expansion is positive and persisting but highly insignificant. Such empirical findings lead us to examine similar system dynamics, but despite this, we are only interested in the effects generated by quantitative easing as the largest and most commonly known unconventional measure.

\section{Methodology: Research method and data sources}

For the research conducted in this paper, we use a recursive VAR model to grasp the dynamics and significance of UMP shocks to the Eurozone economy. Until the introduction of the VAR models by Professor Sims in 1980, the general macroeconomic 
modeling was conducted by linear regressions or autoregressive models, which can be useful in some situations, but fail to grasp the overall system dynamics. Unlike other models, the VARs include only endogenous variables, even though exogenous components can be added. Each variable in the system is modeled on behalf of its own lagged values as well as lagged values of other model variables. These models are useful in analyzing the impact of systemic shocks on specific variables that are closely intertwined and based on the impulse response analysis (Trpkova, 2014). For a broader theoretical explanation, we highly recommend the works of Lütkepohl (2005), Asteriou and Hall (2011), and Trpkova (2014).

Our main objective is testing the following set of hypotheses through the IRF (impulse response functions) analysis to identify the overall system dynamics and not the specific parameters generated by the model.

Hypothesis 1: Unconventional monetary measures generate a positive and signifcant reaction of the output and the price level in the Eurozone. Having in mind that output fluctuations are key in understanding the economic state, we aim to observe the industrial production's reaction to balance sheet shocks. Depending on the model output we want to test whether the price level reacts vigorously and leads to a permanent rise of inflation, as theoretically expected.

Hypothesis 2: Expansive monetary policy at the zero-lower bound further depresses the negative EONIA-MRO spread and leads to significantly less financial stress perception in the economy. The main generators of economic growth are both relaxed borrowing costs for banks, which eventually spreads throughout the broad economy, and the perception of financial risk. They are specifically targeted by the asset purchase incorporated in the quantitative easing and thus they can be evaluated alongside the program's effectiveness. We propose a five variable model using monthly data ranging from 2014M5 to 2018M12. This timeline is deliberately chosen because:

- up until 2014, the Eurozone was under constant economic shocks and financial threats which radically distort the estimated model's results,

- the quantitative easing is of our main interest as it began just a year later and was discussed openly during 2014 and implemented in 2015 (giving an almost one year of prior system accommodation in our model), and

- we want to check whether the system transmission has persistent dynamics based on similar empirical findings for a different timeline than ours.

Besides, we chose this time interval unlike the previous researches in line with our belief that the usage of the UMP is a continuous process, and thus their true impact should be analyzed taking into account the period after their ending. 
That way, taking the balance sheet expansion during the usage of the quantitative easing not only provides a piece of empirical evidence on its impact but incorporates all the previously used measures by the ECB instead.

Data are taken from the ECB Statistical Data Warehouse, Eurostat, and Federal Reserve Bank of St. Louis Economic Research - FRED database. Our recursive VAR model is based on a Cholesky identification of variables, ordering them on behalf of their contemporaneous relationship. This approach restricts these connections into a lower-triangular matrix where the first variable is not influenced by any other on a contemporaneous level, while the last one is under the complete contemporaneous impact of every previous variable in the system. We place the financial stress indicator as last in the model, since we believe that the level of output, inflation, interest rate spread, and balance sheet size are categories that do have a contemporaneous impact on the level of financial stress in the economy. The p-lagged VAR model can be represented in a reduced equation form:

$$
\mathrm{y}_{\mathrm{t}}=\mathrm{A}_{0}+\mathrm{A}_{1} \mathrm{y}_{\mathrm{t}-\mathrm{p}}+e_{\mathrm{t}}
$$

where $y_{t}$ is a ( $\left.n \times 1\right)$ vector of endogenous variables, $A_{0}$ is a ( $\left.n \times 1\right)$ vector of constants, $A_{1}$ is a ( $\left.\mathrm{x} \times \mathrm{n}\right)$ matrix of coefficients to be estimated, and is a ( $\left.\mathrm{n} \times 1\right)$ vector of white noise innovations.

However, we would like to present the complete set of five equations in the model followed by a table of explanation for the measure and abbreviation of each of the included variables:

$$
\begin{aligned}
& \mathrm{IP}_{\mathrm{t}}=\alpha_{10}+\beta_{11} \mathrm{IP}_{\mathrm{t}-1}+\beta_{12} \mathrm{HICP}_{t-1}+\beta_{13} \text { EONIAs }_{t-1}+\beta_{14} \mathrm{~b}_{t-1}+\beta_{15} \mathrm{CISS}_{\mathrm{t}-1}+\mathrm{e}_{1 \mathrm{t}} \\
& \text { HICP }_{\mathrm{t}}=\alpha_{20}+\beta_{21} \mathrm{IP}_{\mathrm{t}-1}+\beta_{22} \text { HICP }_{\mathrm{t}-1}+\beta_{23} \text { EONIAs }_{\mathrm{t}-1}+\beta_{24} \mathrm{~b}_{\mathrm{t}-1}+\beta_{25} \mathrm{CISS}_{\mathrm{t}-1}+\mathrm{e}_{2 \mathrm{t}} \\
& \text { EONIAs }_{t}=\alpha_{30}+\beta_{31} \text { IP }_{t-1}+\beta_{32} \text { HICP }_{t-1}+\beta_{33} \text { EONIAs }_{t-1}+\beta_{34} b_{t-1}+\beta_{35} \text { CISS }_{t-1}+e_{3 t} \\
& b_{t}=\alpha_{40}+\beta_{41} I_{t-1}+\beta_{42} \text {HICP}_{t-1}+\beta_{43} \text { EONIAS }_{t-1}+\beta_{44} b_{t-1}+\beta_{45} \text { CISS }_{t-1}+e_{4 t} \\
& \mathrm{CISS}_{\mathrm{t}}=\alpha_{50}+\beta_{51} \mathrm{IP}_{\mathrm{t}-1}+\beta_{52} \mathrm{HICP}_{\mathrm{t}-1}+\beta_{53} \mathrm{EONIAs}_{\mathrm{t}-1}+\beta_{54} \mathrm{~b}_{\mathrm{t}-1}+\beta_{55} \mathrm{CISS}_{\mathrm{t}-1}+\mathrm{e}_{5 \mathrm{t}}
\end{aligned}
$$

Table 1: Description of model variables

\begin{tabular}{|l|l|l|}
\hline \multicolumn{1}{|c|}{ Variables } & \multicolumn{1}{|c|}{ Abbreviation } & \multicolumn{1}{c|}{ Measurement } \\
\hline Industrial production & IP & $\begin{array}{l}\text { Index of industrial production }(2015 \mathrm{M} 05=100) \\
\text { transformed in percentage points }\end{array}$ \\
\hline $\begin{array}{l}\text { Harmonized Index of } \\
\text { Consumer Prices }\end{array}$ & HICP & $\begin{array}{l}\text { HICP index }(2015 \mathrm{M} 05=100) \text { transformed in } \\
\text { percentage points }\end{array}$ \\
\hline $\begin{array}{l}\text { EONIA-MRO interest rate } \\
\text { spread }\end{array}$ & EONIAs & Interest rate spread in percentage points \\
\hline $\begin{array}{l}\text { Eurosystem consolidated ba- } \\
\text { lance sheet total asset size }\end{array}$ & b & $\begin{array}{l}\text { Natural logarithm of the Eurosystem total } \\
\text { assets size }\end{array}$ \\
\hline $\begin{array}{l}\text { Composite Indicator of } \\
\text { Systematic Stress }\end{array}$ & CISS & Index points \\
\hline
\end{tabular}

* All variables are measured on Eurozone level and they are not country-specific. 
Furthermore, we can express the previously shown equations into the following matrix form:

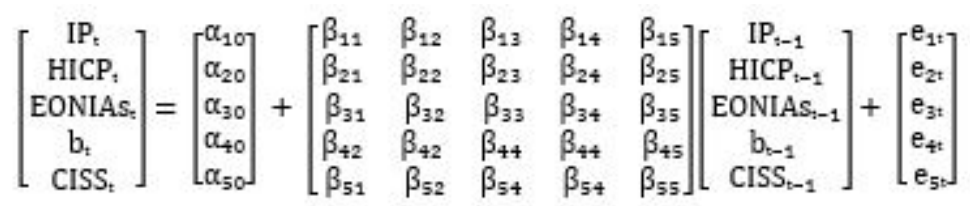

Since the main idea is analyzing impulse response functions, it's logical to take into account the long-term relationship between the variables. Even though it's rare, modeling VAR processes with variables containing unit roots is not completely strange. However, it's largely discussed whether to use this particularly 'brave' approach or to differentiate the non-stationary series and how it can generate the problem of spurious regression. According to Sims, Stock, and Watson (1990), it's not necessary to insist on stationarity since differentiating as a form of series transformation severely impairs long-run relationships between the variables in the model, so continuation with data in levels is thus accepted. A similar approach is used by Peersman (2011), Gambacorta, Hofmann, and Peersman (2014) as well as Hálová (2015), all noting that it's intentionally done to preserve the long-run relationship in the system. According to these approaches we continue with five variable recursive VAR in levels as differentiation showed to severely impair the model output based on the suggested lag length.

The basic correlation analysis indicates a strong positive relationship between the total assets of the Eurosystem with the industrial production and the price level. This immediately signals partial confirmation of the first hypothesis. A strong negative relationship is found between the main variable (b) and the EONIA-MRO spread, while the estimated negative relationship with the CISS indicator is far weaker. The negative correlation between the total assets and the EONIA-MRO spread is understood in terms of widening negative spread which further depress funding costs for banks - a point which we want to confirm and we perceive as crucial in generating economic growth through the lending channel. 
Graph 1: Overall variable dynamics, 2014M5-2018M12
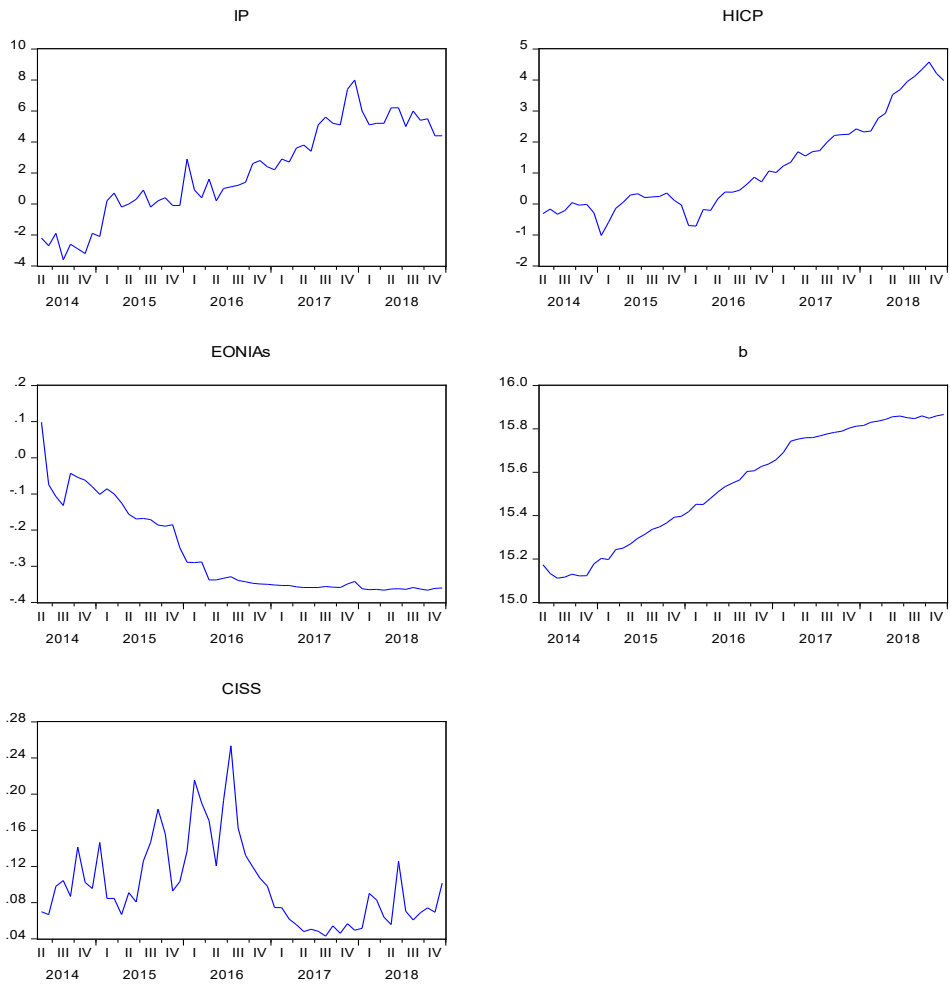

Source: Authors'depiction

On behalf of VAR modeling, it is a standard procedure to check for possible unit roots in the selected variables. We conduct the Augmented Dickey-Fuller (ADF) and the Phillips-Perron (PP) tests. Every variable in the model is integrated of order one I (1), meaning that the series are non-stationary at levels. An additional KwiatkowskiPhillips-Schmidt-Shin (KPSS) test was needed to get relevant results for the variable $b$, where we obtained the previous conclusions of non-stationarity. However, since we focus on the long-run relationship between the variables we decide not to incorporate the first differences of the variables in the model.

Table 2: Correlation coefficients between the variables of interest

\begin{tabular}{|c|r|r|r|r|c|}
\hline & \multicolumn{1}{|c|}{ IP } & \multicolumn{1}{c|}{ HICP } & EONIAs & b & CISS \\
\hline IP & 1.000000 & & & & \\
\hline HICP & 0.826940 & 1.000000 & & & \\
\hline EONIAs & -0.832466 & -0.661822 & 1.000000 & & \\
\hline b & 0.941725 & 0.858183 & -0.917920 & 1.000000 & \\
\hline CISS & -0.424443 & -0.489476 & 0.123751 & -0.357429 & 1.000000 \\
\hline
\end{tabular}

Source: Authors'calculations 
With the idea for estimating the most parsimonious model, we further conduct basic optimal lag length tests which suggest that $\mathrm{p}=1$ lags are the most appropriate, based on the results of 3 out of 5 tests indicating that lag. Also, the model has been tested with a higher level of lags, each not providing appropriate results for the stability and residual tests. On that note, we represented the equations of the model with one lag.

Table 3: Optimal lag length selection criteria

\begin{tabular}{|c|c|c|c|c|c|c|}
\hline Lag & $\log L$ & LR & FPE & $\mathrm{AIC}$ & $\mathrm{SC}$ & HQ \\
\hline 0 & 63.40071 & NA & $8.55 \mathrm{e}-08$ & -2.085740 & -1.904905 & -2.015630 \\
\hline 1 & 347.7908 & 507.8395 & $8.13 \mathrm{e}-12 *$ & -11.34967 & $-10.26466^{*}$ & $-10.92902 *$ \\
\hline 2 & 365.8513 & 29.02574 & $1.07 \mathrm{e}-11$ & -11.10183 & -9.112646 & -10.33063 \\
\hline 3 & 393.9927 & 40.20208 & $1.01 \mathrm{e}-11$ & -11.21403 & -8.320666 & -10.09228 \\
\hline 4 & 414.7983 & 26.00695 & $1.31 \mathrm{e}-11$ & -11.06422 & -7.266690 & -9.591928 \\
\hline 5 & 454.4405 & $42.47376^{*}$ & $9.39 \mathrm{e}-12$ & -11.58716 & -6.885450 & -9.764316 \\
\hline 6 & 491.6239 & 33.19953 & $8.32 \mathrm{e}-12$ & $-12.02228 *$ & -6.416399 & -9.848894 \\
\hline
\end{tabular}

* indicates the optimal lag length estimated by the criteria

Source: Authors'calculations

After estimating the recursive VAR (1) in levels we proceed with testing for model stability and conducting some residual tests related to the existence of autocorrelation and heteroscedasticity. The characteristic roots polynomial test shows that each of the inverse roots is within the unit circle which indicates model stability. Testing for autocorrelation is conducted through the popular Portmanteau autocorrelation test and the Autocorrelation LM test. The former indicates no presence of autocorrelation at the $1 \%$ level, while the latter fails to find serial correlation on each of the first six lags. Consequently, we conclude that there is no evidence of autocorrelation in the specified model. As a final test, we check for the presence of heteroscedasticity. With the p-value standing at 0.0618 , it is observed that there is no heteroscedasticity problem in the model and thus residuals are taken as homoscedastic. With this, we proceed with the IRFs results explication.

Table 4: LM autocorrelation test

\begin{tabular}{|r|r|r|r|r|r|l|}
\hline \multicolumn{7}{|c|}{ Null hypothesis: No serial correlation at lag h } \\
\hline \multicolumn{1}{|c|}{ Lag } & \multicolumn{1}{|c|}{ LRE* stat } & \multicolumn{1}{c|}{ df } & \multicolumn{1}{c|}{ Prob. } & \multicolumn{1}{c|}{ Rao F-stat } & df & Prob. \\
\hline 1 & 18.91585 & 25 & 0.8011 & 0.745857 & $(25,153.8)$ & 0.8026 \\
\hline 2 & 29.10829 & 25 & 0.2594 & 1.184565 & $(25,153.8)$ & 0.2618 \\
\hline 3 & 28.43221 & 25 & 0.2883 & 1.154620 & $(25,153.8)$ & 0.2908 \\
\hline 4 & 19.58562 & 25 & 0.7682 & 0.773863 & $(25,153.8)$ & 0.7698 \\
\hline 5 & 22.22293 & 25 & 0.6228 & 0.885249 & $(25,153.8)$ & 0.6251 \\
\hline 6 & 23.57513 & 25 & 0.5440 & 0.943051 & $(25,153.8)$ & 0.5465 \\
\hline
\end{tabular}


Table 5: LM autocorrelation test

\begin{tabular}{|r|r|r|r|r|r|l|}
\hline \multicolumn{7}{|c|}{ Null hypothesis: No serial correlation at lags 1 to $h$} \\
\hline \multicolumn{1}{|c|}{ Lag } & \multicolumn{1}{|c|}{ LRE* stat } & \multicolumn{1}{c|}{ df } & \multicolumn{1}{c|}{ Prob. } & \multicolumn{1}{c|}{ Rao F-stat } & \multicolumn{1}{c|}{ df } & Prob. \\
\hline 1 & 18.91585 & 25 & 0.8011 & 0.745857 & $(25,153.8)$ & 0.8026 \\
\hline 2 & 55.49109 & 50 & 0.2755 & 1.126003 & $(50,167.5)$ & 0.2857 \\
\hline 3 & 93.57983 & 75 & 0.0721 & 1.302745 & $(75,152.7)$ & 0.0862 \\
\hline 4 & 145.5585 & 100 & 0.0020 & 1.630426 & $(100,131.5)$ & 0.0043 \\
\hline 5 & 182.4467 & 125 & 0.0006 & 1.670836 & $(125,108.3)$ & 0.0032 \\
\hline 6 & 220.8922 & 150 & 0.0001 & 1.706553 & $(150,84.2)$ & 0.0038 \\
\hline
\end{tabular}

Source: Authors'calculations

\section{Results and discussions}

Analyzing the impulse response functions is one of the key indicators of shock distribution throughout the model. They provide a helpful explanation of the overall model dynamics as well as the transmission of shocks. Since our two hypotheses are based on the impact generated by the balance sheet expansion on other variables, we decide to include only those IRFs for final result simplicity.

As expected, the balance sheet expansion represented by the total assets of the Eurosystem has a positive impact on the industrial production taken as output proxy as well as the level of inflation. However, the transmission of the shocks is different for these two variables. The industrial production response is estimated to be 2.24 times greater than that of the inflation, reaching its peak four periods after the initial shock with a maximum impact of 15 b.p. After the $5^{\text {th }}$ period, the shock to the industrial production slowly degrades down to zero. Taking the standard deviation intervals into account, this effect is significant after the $3^{\text {rd }}$ period and loses its significance from the $26^{\text {th }}$ period onwards. On the other hand, our findings considerably differ in the periods of transmission compared to the work of Boeckx, Dossche, and Peersman (2014), possibly due to the different output proxies used in the models.

The HICP reaction seems to be much more persistent but weaker in effect, reaching its peak of 6.7 b.p. exactly two years after the initial shock. In the next three periods, the level of impact persists after which begins a slow process of degrading. The confidence intervals indicate an insignificant shock up until the $10^{\text {th }}$ period. The reaction of the total assets on their shock is positive as expected with a downward trend and gradually becomes insignificant after the $28^{\text {th }}$ period. Generally, we can conclude that the inflation response is much more persistent, but much less intensive compared to the output, in line with Gambacorta, Hofmann, and Peersman (2014). As a result, the first hypothesis can be completely accepted by the model. 
On the other hand, we confirm the expected and empirically proven negative relationship between the balance sheet size and the EONIA-MRO spread and the CISS index. However, if these shocks are compared with the previous two variables, the total assets shock impact on these two seems to be substantially smaller. The spread between the EONIA rate and the MRO rate further depresses into the negative zone, making it wider. It reaches its peak of -0.48 b.p. in the $6^{\text {th }}$ period, keeping that level for the further four periods. On the other side, this effect becomes insignificant after the $17^{\text {th }}$ period onward.

Contrary to the second hypothesis that the total assets of the Eurosystem generate a significant lowering in the level of financial stress in the EA, our model fails to confirm that. Due to the Cholesky decomposition, the first three variables are not under the contemporaneous impact of the balance sheet expansion, unlike the variable CISS. We place the financial stress indicator as last in the model, since we believe that the level of output, inflation, interest rate spread, and balance sheet size are categories that do have a contemporaneous impact on the level of financial stress in the economy. The immediate impact of total assets shocks generates a lowering of the CISS by -0.0022 points, reaching its peak in the next period with -0.0035 points. After this point, the shock gradually loses its impact and slowly degrades towards zero. We conclude that a negative and insignificant relationship is observed. Our model accepts the entire first hypothesis but the second one, regarding financial stress, cannot be completely accepted and thus it is partially denied.

To check for model robustness, we substitute the variable $b$ with a SR (shadow policy rate) variable, which can be taken as a proxy for the UMP following the approach of Hálová (2015) and Hafemann and Tillmann (2017). This is not a common approach but it slowly gains ground in model estimation. It incorporates the levels of asset purchases by the central bank into the standard interest rate policy, generating an interest rate that is not restricted by the zero lower bound (the original approach is included in $\mathrm{Wu}$ and $\mathrm{Xia}, 2016$ ). Results show that this model gives a fair explanation of the theoretical expectations of model performance if a negative rate is considered. Additionally, it provides considerably better stability and residual diagnostics test results. The main problems are, however, the especially wide confidence intervals making the IRFs insignificant in most cases. Shocks to the industrial production and inflation can be considered much stronger in response compared to our benchmark model, while the shocks to EONIA-MRO spread and the CISS are not far different from the first estimation. Finally, based on our research we can conclude that the quantitative easing did generate the expected theoretical responses on the focused variables. Their level of response to balance sheet shocks is debatable though. While the implemented measures by the ECB have proven to stimulate economic growth, price level, and further lower borrowing costs for banks, their final result might not 
have fulfilled the expectations. However, we must note that the reaction of the targeted variables is not a product of quantitative easing only. The usage of prior measures still affects the Eurozone thanks to the lags in the transmission mechanism.

Graph 2: Impulse response functions; benchmark model - left-hand side, alternative model - right-hand side

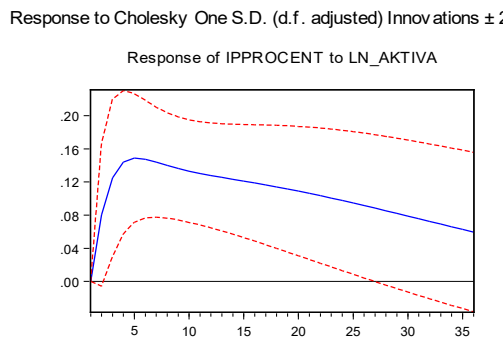

Response of INF_PROCENT_2015 to LN_AKTIVA

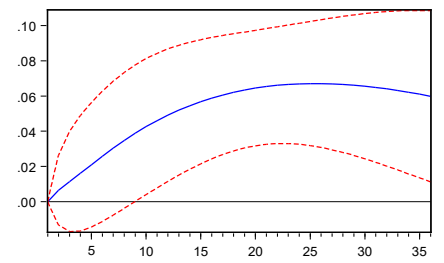

Response of EONIA_SPREAD to LN_AKTIVA

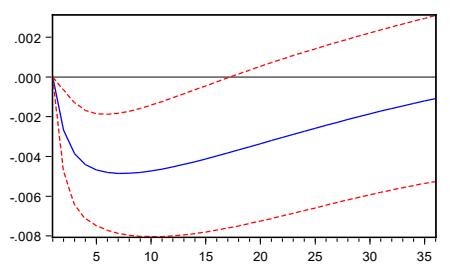

Response of LN_AKTIVA to LN_AKTIVA

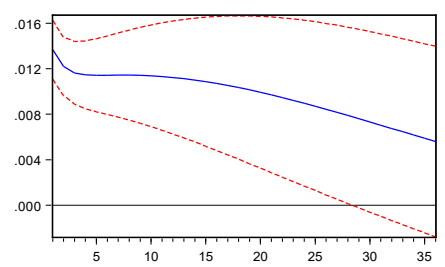

Response of CISS to LN_AKTIVA

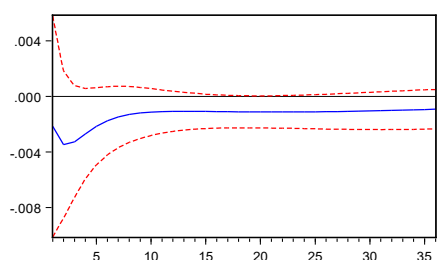

Response to Cholesky One S.D. (d.f. adjusted) Innov ations \pm 2 S.E.

Response of IPPROCENT to SR

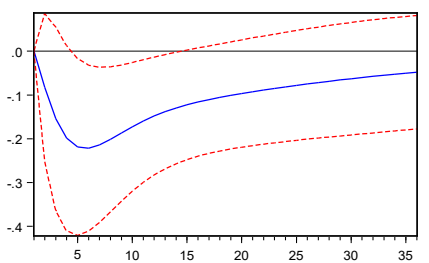

Response of INF_PROCENT_2015 to SR

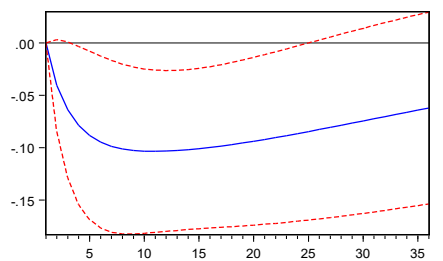

Response of EONIA_SPREAD to SR

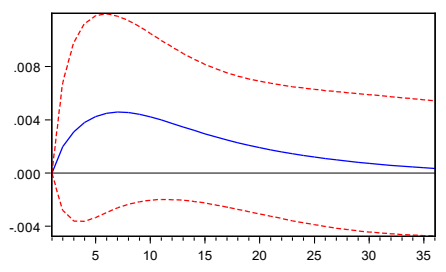

Response of SR to SR

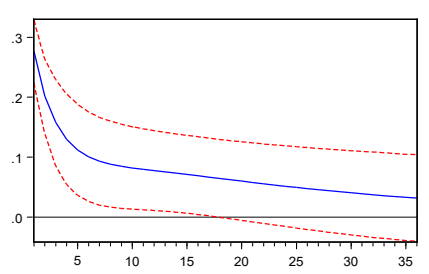

Response of CISS to SR

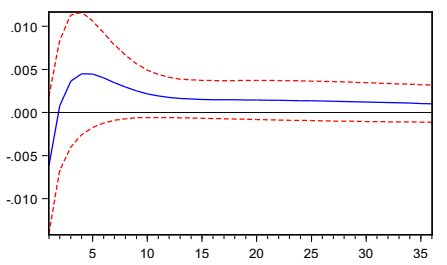

* the variables IP, HICP, EONIAs, and $b$ are represented by the abbreviations IPPROCENT, INF_PROCENT, EONIA_SPREAD, and LN_AKTIVA, respectively. 


\section{Unconventional monetary measures as a part of the standard monetary arsenal - thoughts and expectations for the future}

When the monetary authorities began losing their power, the usage of UMP in tackling specific market distortions and correcting primary objective achievements was seen as revolutionary. Immediately when the interest rate policy became restricted by the ZLB (zero lower bound), the central banks quickly shifted towards alternative and quick approaches, mainly through liquidity injection in the economy. The usage of this approach for the full 12 years opens the question of whether the UMP might become a part of the standard instruments of the central banks. Friedman (2014) notes that forward guidance probably failed to generate the expected impact mainly because of the lack of empirical evidence. On the other hand, he indicates that asset purchases proved to be highly accommodative. Furthermore, he suggests that quantitative easing can de facto coexist with the traditional interest rate policy, successfully integrating into the standard monetary arsenal over time. Contrary to the previous statement it is believed that inadequately set policy for balance sheet expansion, may not be particularly effective in reviving the pre-crisis level of growth. This sets a series of possible obstacles in the implementation of the monetary policy and guiding the expectations of the economic agents. The central banks should instead focus on alternative and improved communication channels followed by an increase in their credibility (Lombardi, Siklos, and St. Amand, 2018). Belke (2016) focuses on the exit strategies from the highly accommodative monetary policy persisting at the moment, noting that it should be done gradually once the banking sector and the financial markets are back on track isolated from potential instabilities. The main reason behind this is avoiding inflationary pressures emerging from the high levels of excess liquidity which ultimately tackles down the 'almost perfect' results from the implemented inflation targeting regimes.

We reject the belief that the UMP will be abolished in near future nor they would be completely substituted by conventional instruments like the pre-crisis period. They might incorporate them into the conventional monetary arsenal, however, used temporary and non-regularly. Their usage will be strictly targeted towards specific market distortions where they are proven to be much more effective than traditional interest rate policy (see Friedman, 2014). The introduction of digital national values is closer than ever. Their announcement plans and discussions are much louder than a few years back. Unlike the cryptocurrencies present today, institutionally backed digital currency might solve the high risk and uncertainty problems. When there is no physical currency, practically the concept of flight to cash is impossible once the effective lower bound is breached. This means that the implementation of the required stabilization rate is by no means restricted from further lowering. 
This phenomenon will leave a much wider space for the central banks to conduct a negative interest rate policy. Even though this concept persists as an idea, larger discussions are present in Russia, China, and Sweden (for similar topics we kindly instruct you to check Hauck and Neyer, 2010; Fischer, 2016; or for dual national currencies check Rogoff, 2017).

\section{CONCLUSIONS}

After the dramatic monetary shift in the post-crisis period, most of the research papers focus on different aspects and relationships in the macroeconomic and financial system to create a broad picture of how the unconventional measures are implemented, why it is done in a certain way and what the expectations for the future are. Our research aims to grasp these issues through a recursive VAR approach with our focus targeted specifically on the period of the asset purchase programme implemented by the ECB. Since quantitative easing accounts for most of the balance sheet expansion of the Eurosystem, the impact and transmission of UMP shocks in our model can be understood as a result of this monetary approach. However, one must not forget that the real impact of unconventional asset purchases and liquidity providing operations have a prolonged impact and part of the variable responses are due to previous measures incorporated by the ECB.

We found that the usage of quantitative easing, probably as a measure of last resort, impacts the output, proxied by the industrial production, much more than inflation. This relationship correlates with the rather weak inflation persisting in the EA after the sovereign debt crises. Contrary to the level of balance sheet expansion, inflation stays at low levels and this might be a serious issue that ECB needs to tackle quickly amid the COVID-19 pandemic, both quantitatively and qualitatively. The hump-shaped impulse response is something previously observed in studying monetary transmission on output and prices. Our model confirms this persistent behavior while the impact seems to be much smaller. On that note, we conclude that the quantitative easing did provide monetary and economic stimulus in the EA, but much less than expected. With the given model results, we can finally say that the first hypothesis is completely accepted while the second is partially denied. One might think of the UMP as a real non-standard measure and others might talk about it integrating into the conventional monetary arsenal in the future. We firmly believe that this approach in conducting monetary policy is here to stay and is already part of standard monetary policy. Their constant usage for more than a decade means that the monetary policy is already changed and thus they cannot be considered as pure unconventional measures anymore. 


\section{REFERENCES}

1. Asteriou, D. and Hall, G. S. (2011). "Applied Econometrics". 2nd Edition, Palgrave Macmillan, pp. 319-333.

2. Baldwin, R. E. and Wyplosz, C. (2009). "The economics of European integration”. McGraw-Hill Higher Education, pp. 316-345, 471-516.

3. Boeckx, J., Dossche, M., and Peersman, G. (2014). "Effectiveness and transmission of the ECB's balance sheet policies". International Journal of Central Banking, 13(1), pp. 297-333.

4. Carlin, W. and Soskice, D. (2005). "The 3-equation New Keynesian Model---a graphical exposition". The BE Journal of Macroeconomics, 5(1), pp. 1-36.

5. Eser, F. and Schwaab, B. (2013). "Assessing asset purchases within the ECB's securities markets programme", working paper no. 1587, European Central Bank, Frankfurt am Main, Germany.

6. Fischer, S. (2016). "Monetary policy, financial stability, and the zero lower bound". American Economic Review, 106(5), pp. 39-42.

7. Friedman, B. M. (2014). "Has the financial crisis permanently changed the practice of monetary policy? Has it changed the theory of monetary policy?". Working paper 20128. National Bureau of Economic Research, Cambridge, MA 02138, May 2014.

8. Gambacorta, L., Hofmann, B., and Peersman, G. (2014). "The effectiveness of unconventional monetary policy at the zero lower bound: A cross-country analysis". Journal of Money, Credit and Banking, 46(4), pp. 615-642.

9. Hafemann, L., and Tillmann, P. (2017). "The aggregate and country-specific effectiveness of ECB policy: Evidence from an external instruments (VAR) approach". (No. 20-2017), Joint Discussion Paper Series in Economics.

10. Hálová, K. (2015). "The Impact of Unconventional Monetary Policy of ECB to Central and Eastern European Countries: A Panel VAR Analysis". Master Thesis, Charles University in Prague.

11. Hauck, A. and Neyer, U. (2010). "The euro area interbank market and the liquidity management of the Eurosystem in the financial crisis". Heinrich-Heine-University Duesseldorf, Economics, Finance, and Taxation Discussion Paper, (2).

12. Lombardi, D., Siklos, P., and St. Amand, S. (2018). "A survey of the international evidence and lessons learned about unconventional monetary policies: Is a 'new normal' in our future?". Journal of Economic Surveys, 32(5), pp. 12291256. 
13. Lütkepohl, H. (2005). "New Introduction to Multiple Time Series Analysis", Springer Science \& Business Media, pp. 13-66.

14. Peersman, G. (2011). "Macroeconomic effects of unconventional monetary policy in the euro area", working paper No. 1397, European Central Bank, Frankfurt am Main, Germany.

15. Rogoff, K. (2017). "Dealing with monetary paralysis at the zero bound". Journal of Economic Perspectives, 31(3), pp. 47-66.

16. Sims, C. A., Stock, J. H., and Watson, M. W. (1990). "Inference in linear time series models with some unit roots". Econometrica: Journal of the Econometric Society, 58(1), pp. 113-144.

17. Trpkova, M. (2014). „Applied vector autoregressive models in macroeconomic modeling“, Ph.D. Thesis, Faculty of Economics - Skopje, St. Cyril and Methodius University, pp. 114-185.

18. Zabala, J. A., and Prats, M. A. (2020). "The unconventional monetary policy of the European Central Bank: Effectiveness and transmission analysis". The World Economy, 43(3), pp. 794-809. 
Filip Peovski

Gjorgji Gockov

\section{PROCJENA NEKONVENCIONALNIH MJERA EVROPSKE CENTRALNE BANKE - REKURZIVNI VAR PRISTUP}

\section{SAŽETAK}

Pokazalo se da je korištenje nekonvencionalnih monetarnih mejra od velike važnosti za održavanje monetarne i ekonomske stabilnosti nakon Velike recesije. Međutim, cilj našeg istraživanja je da testiramo ovaj zaključak kroz uticaj kvantitativnog olakšavanja koje je sprovela Evropska Centralna Banka. Posmatrano kroz generisane šokove u bilansu Evrosistema kao našu glavnu promenljivu, testirali smo da li je kvantitativno olakšavanje ponovo uspostavilo ekonomski rast i povećalo nivo cijena, uglavnom preko smanjenja troškova pozajmljivanja za banke, pomažući tako u oporavku nakon krize. Da bismo dokazali svoje hipoteze, koristimo rekurzivni VAR model procenjen u nivoima koristeći podatke za period 2014M05-2018M12. Model uključuje promenljive kao što su industrijska proizvodnja i HICP u evrozoni i finansijske komponente kao što su EONIA-MRO raspon i CISS indeks. Rezultati pokazuju da proširenje konsolidovanog bilansa Evrosistema ima pozitivan i privremeni uticaj na industrijsku proizvodnju i HICP u Evrozoni, ali čini se da je reakcija prethodnih 2,24 puta veća. S druge strane, otkrivamo da kvantitativno olakšavanje ima očekivani negativni uticaj na širenje negativnog EONIA-MRO raspona. Dodatno, nismo mogli da potvrdimo teoretski očekivani prilagodljiv uticaj na pokazatelj finansijskog stresa.

Ključne reči: Nekonvencionalne monetarne mere, stabilnost cena, kamatne stope, rekurzivni VAR model

JEL: C32, E43, E52, E58 